
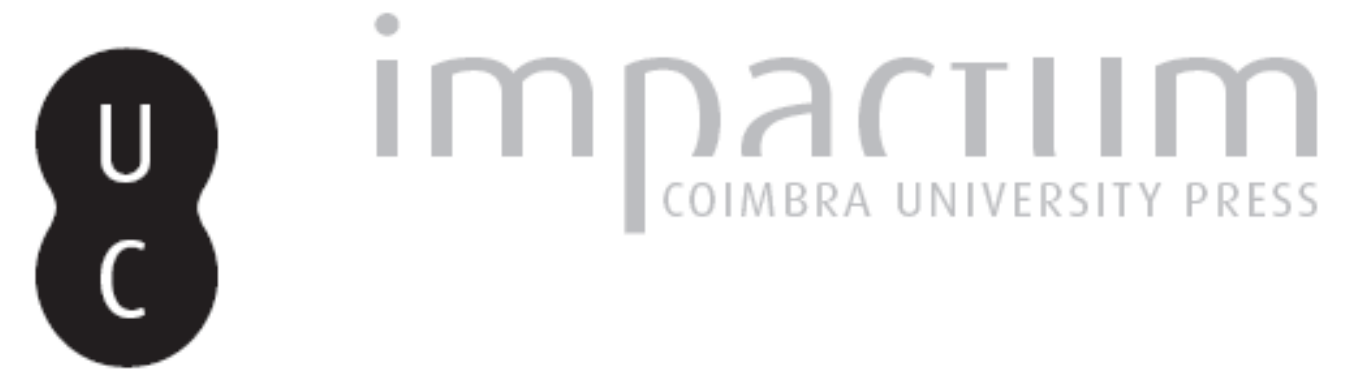

\title{
[Recensão a] GORDON, J. (2012) PLATO'S EROTIC WORLD: FROM COSMIC ORIGINS TO HUMAN DEATH
}
Autor(es):
Riegel, Nicholas
Publicado por: Annablume Clássica; Imprensa da Universidade de Coimbra
URL persistente:
URI:http://hdl.handle.net/10316.2/36135
DOI:
DOI:http://dx.doi.org/10.14195/1984-249X_14_13
Accessed : $\quad$ 26-Apr-2023 16:37:27

A navegação consulta e descarregamento dos títulos inseridos nas Bibliotecas Digitais UC Digitalis, UC Pombalina e UC Impactum, pressupõem a aceitação plena e sem reservas dos Termos e Condições de Uso destas Bibliotecas Digitais, disponíveis em https://digitalis.uc.pt/pt-pt/termos.

Conforme exposto nos referidos Termos e Condições de Uso, o descarregamento de títulos de acesso restrito requer uma licença válida de autorização devendo o utilizador aceder ao(s) documento(s) a partir de um endereço de IP da instituição detentora da supramencionada licença.

Ao utilizador é apenas permitido o descarregamento para uso pessoal, pelo que o emprego do(s) título(s) descarregado(s) para outro fim, designadamente comercial, carece de autorização do respetivo autor ou editor da obra.

Na medida em que todas as obras da UC Digitalis se encontram protegidas pelo Código do Direito de Autor e Direitos Conexos e demais legislação aplicável, toda a cópia, parcial ou total, deste documento, nos casos em que é legalmente admitida, deverá conter ou fazer-se acompanhar por este aviso.

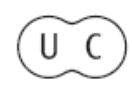




\section{4}

jan/jun

2015

issn 2179-4960 e-issn 1984-249-X
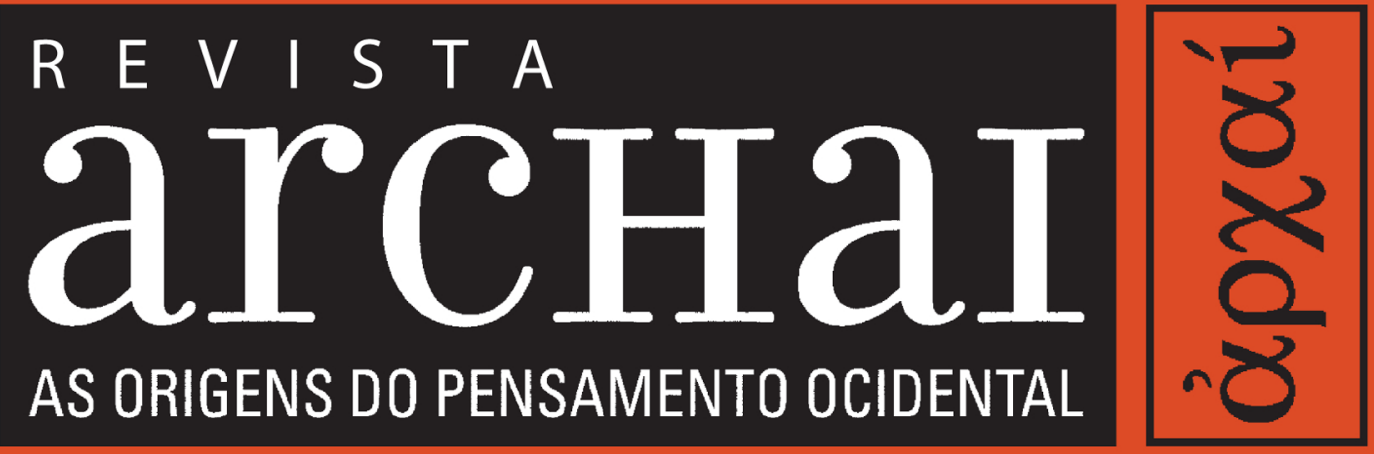

ARCHAI JOURNAL: ON THE ORIGINS OF WESTERN THOUGHT

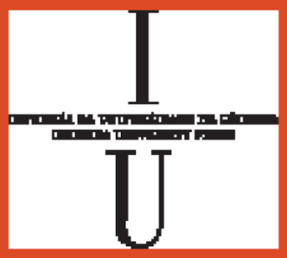

\section{archaI}

AS ORIGENS Do PENSAMENTO OCIDENTAL 


\section{GORDON, J. (2012) PLATO'S EROTIC WORLD: FROM COSMIC ORIGINS TO HUMAN DEATH. CAMBRIDGE, CAMBRIDGE UNIVERSITY PRESS.}

RIEGEL, N. (2014). Resenha. GORDON, J. (2012) Plato's Erotic World: From Cosmic Origins to Human Death. Cambridge, Cambridge University Press. Archai, n. 14, jan - jun, p. 159-162

DOI: http://dx.doi.org/10.14195/1984-249X_14_13
Universidade de Brasília, Brasília, Brasil. (nriegel95@gmail.com)
Nicholas Riegel

$I_{n}$ this work, Jill Gordon presents a contribution to the scholarship that must be read by anyone interested in the subject of erotic love, eros, and related issues in Plato. The book is written in a clear style which will be accessible to undergraduates, and it contains insights and new interpretations which will challenge and be useful to more advanced scholars as well. Though the lack of a conclusion would seem to indicate that her book is not primarily written in the form of an argument, Gordon wants to defend several theses. The main goal of the book is to highlight the significance of those passages in the Platonic corpus having to do with eros, which are outside of what are traditionally considered Plato's erotic dialogues, namely, Symposium, Phaedrus, Charmides, Lysis, Alcibiades I, and perhaps Republic (1). While she will have certain things to say about these dialogues, especially Phaedrus and Alcibiades I, she will focus on the role of eros in Timaeus, Cratylus, Protagoras, Parmenides, Theaetetus, and Phaedo. Within these dialogues her main aim is to show how eros is part of our divine origin, and how through proper cultivation of eros we may return to that original state. The proper cultivation will involve, first, becoming aware of one's ignorance and adopting an interrogative outlook. Second, it 
will require the courage to undertake a long and difficult task whose outcome is uncertain. It will also require guides who know the soul, and who are adept both at matchmaking and leading their charges to self-knowledge. And finally she addresses the connection between eros and the memory of our original state to which we strive to return. Thus Gordon takes us on a circular journey beginning with our divine origins in the Timaeus, then descending to the difficulties of our embodied state in the Cratylus, Protagoras, Parmenides and Theaetetus, and then finally returning to our nostos, our journey home, and re-attainment of that original state, in the Phaedo.

In the first chapter, Gordon is primarily concerned to establish two points. The first is that, contrary to the traditional reading of the Timaeus, eros is part of our original noetic condition and thus eros, or at least the capacity for it, is part of the Demiurge's contribution to the human soul, as opposed to being the work of the lesser gods. The second and for Gordon related point is that eros is not an emotion and it is not part of the epithumetic desires, which at least in Republic Book IV constitute the third part of the soul. Gordon wants to establish the latter point because, among other reasons, if eros were an emotion or among the epithumetic desires then it would be part of the work of the lesser gods in the Timaeus. And, according to Gordon, this would imply that eros is not due to the creative activity of the Demiurge himself and therefore that it is not part of our original noetic condition.

Her main argument for the view that the Demiurge is responsible for eros in the human soul revolves around the interpretation of two passages, Timaeus 42a-b and 69c-e, which seem to say much the same thing. Both seem to describe how the affections, such as fear, anger, and eros, come to be in the human soul in connection with its embodiment. At 69c-e the introduction of these affections (if I may use that word) is clearly the work of the lesser gods. The crucial question is whether the earlier passage, 42a-b, likewise describes the work of the lesser gods. According to Gordon, the traditional interpretation accepts that it does, but Gordon argues that 42a-b describes the Demiurge's own work, and thus that eros, or the capacity for eros, is part of our original noetic and divine condition. Gordon presents three reasons for believing this. First, 42a-b "occurs before the demiurge has handed off responsibility for the mortal soul to the lesser gods. It presents itself as part of the demiurge's long set of instructions and descriptions of his work, which precedes what he assigns to the lesser gods" (16). Second, the affections at 69c-e are presented in a negative light, while they are not so presented at $42 \mathrm{a}-\mathrm{b}$. And third, $69 \mathrm{c}$-e occurs after the "new beginning" at 48a-b, where Timaeus switches from speaking about the causal role of intellect to that of necessity.

In chapters 2 through 5 Gordon explores the four main aspects of eros, which emerge in the context of the self-cultivation required to achieve the return our original noetic state. Chapter 2 mainly concerns the importance of questioning and the interrogative state for eros. She begins with the Cratylus where a homophonic connection is made between the Greek words for 'hero,' 'eros,' and 'ques-

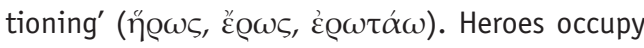
a position between the gods and mortals, much as Diotima describes eros in the Symposium. And Gordon ties Socrates' claim to knowledge of erotics in Symposium to his expertise in questioning. By asking questions, Socrates shows his interlocutors that they do not know what they thought they knew, and thus he instills in them the erotic desire to know the truth. Chapter 3 discusses the courage required to engage in erotic questioning and in the philosophic pursuit generally. Here Gordon takes Parmenides as her starting point, claiming that "eros is a significant philosophical theme" in that dialogue (86). Her grounds for saying so revolve mainly around the fear Parmenides and Socrates share both about the range of the Forms, and about the problems of discontinuity between the realm of the Forms and the concrete realm. This fear is to be overcome by the philosophical exercise exemplified by Parmenides in the second half of the dialogue. Gordon highlights the erotic dimension of gymnastic training in Ancient Greece, and thus connects the second half of the Parmenides with an erotic desire which in some way overcomes the discontinuity between the concrete and abstract 
realms.

In the fourth and fifth chapters Gordon tackles the related issues of matchmaking, self-knowledge, and the necessity of having a good leader or teacher. In the Theaetetus Socrates reveals that matchmaking is part of his maieutic art, and he uses his knowledge of these matters to demonstrate that Theodorus is not a good match for Theaetetus, because, among other reasons, Theodorus does not have a good understanding of Theaetetus' soul. The significance of good matchmaking becomes apparent when we turn to the Alcibiades, where Socrates reveals to Alcibiades that he needs a good teacher in order to achieve self-knowledge, and that in fact Socrates himself would be his best teacher because Socrates understands Alcibiades' soul. In chapter 5 Gordon takes on several of Schleiermacher's arguments against the authenticity of the Alcibiades. She argues that self-knowledge can only be achieved in the company of another, and that it is best achieved in the company of a lover who knows one's soul. Self-knowledge is crucial in order to discover what one truly desires and loves. Thus in helping the beloved achieve self-knowledge the lover also redirects the beloved's eros towards its true objects.

Finally, in the last chapter Gordon addresses the connection between eros and memory in helping us return to our original noetic state in the Phaedo. Here she highlights the example of seeing the lyre or cloak of the beloved as an explanation of the connection between eros and memory. And she challenges the tradition according to which recollection is a purely mental, rational endeavor. Instead Gordon highlights the importance of the senses, of actually seeing the cloak or lyre or equal sticks, in the act of remembering our original condition.

Clearly it is only possible to give the broadest outline Gordon's work here, and many of her most rewarding and challenging insights and interpretations have been left for the reader to discover. At this point, however, I turn to making three evaluations before concluding.

First, while I agree that there is evidence in the Platonic corpus for the view that eros is part of our original noetic condition, I find myself un-persuaded by Gordon's interpretation of the
Timaeus. While not claiming any expertise on that dialogue it seems that on a straightforward reading of Timaeus 42a-b, the Demiurge is merely explaining to the human souls what will happen to them once they are embodied and receive affections such as anger, fear, and love. The passage is preceded by the following: "And putting each in a sort of chariot he showed them the nature of the universe and told

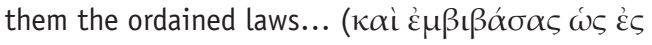

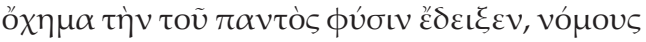

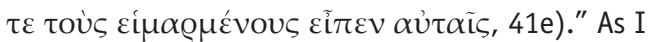
read the text, everything that follows until $42 \mathrm{~d}$ is part of this explanation by the Demiurge to the human souls about what will happen to them, namely that they will receive affections when embodied and that they must control these if they wish to regain their original divine state. This interpretation is supported at the end of the passage where Timaeus states, "Prescribing all these things to them, in order that he might be blameless for the evil of each...

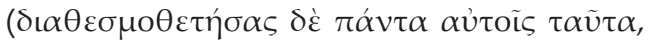

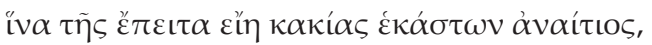
$42 \mathrm{~d})$." So, I see no reason to take $42 \mathrm{a}-\mathrm{b}$ as referring to the Demiurge's own creative activity. It seems, rather, that he is only explaining to them how to live once they received the affections by necessity upon being embodied. And 69c-e further specifies that the embodiment and consequent reception of the affections is the work of the lesser gods. This is not, however, to say that Gordon is wrong to believe that eros is part of our original noetic condition. It is only to say that I think one could find better support for such a thesis elsewhere in the Platonic corpus, e.g. from Symposium where Socrates/ Diotima specifically speaks about the possibility of continuing to feel eros even when one possesses the good (Symposium 200c-d, cf. 206a-7a).

Second, at times I found myself remaining skeptical about Gordon's claims regarding the meanings of certain Greek words and concepts, in particular the claim that they have erotic connotations. She claims, for example that "the horse was used in old comedy as a phallic stand-in" (101), and thus that a possible interpretation of Parmenides' reference to feeling like an old horse at Parmenides $136 \mathrm{e}-7 \mathrm{a}$ is that it is "a playful and raunchy way of 
expressing that he is being asked to "get it up" again in old age..." (102). Even if it is true that the horse is used as a phallic stand-in in old comedy, I do not see that it follows from this that the horse always has erotic connotations, and so I see no reason to impute such connotations to this part of the Parmenides. I feel much the same way about her

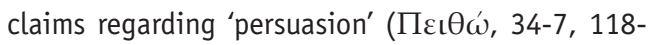

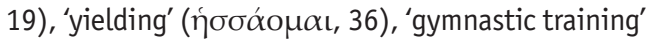
( $\gamma \cup \mu \nu \alpha ́ \alpha \omega, 98)$, 'leading' ( others. Even if these concepts sometimes have erotic connotations, it does not follow that they always have them - or at least more work is needed to establish that they do - and so the reader remains skeptical about the inference that they have such connotations in the passages in question.

Finally, I would like to present a criticism which will reveal my biases most of all. And this is that for me the question of eros in Plato is essentially bound up with the questions of goodness and beauty. In this sense, I think, the strength of Gordon's work is also its weakness. For in focusing on what are traditionally not considered erotic dialogues, it seems to me that certain central issues concerning eros are omitted, which are addressed in the traditional erotic dialogues, especially Symposium and Phaedrus. In the Symposium it is a major revelation that the object of eros is goodness, not beauty (204d-e). And eros is defined as the desire to possess the good forever (206a). And yet Gordon says very little about beauty and even less about goodness. We may infer that, for Gordon, the good which is the proper object of eros is the return to the original noetic condition, and no doubt this is true. But the question remains, why is that original noetic condition good? The Symposium explicitly addresses and rejects the idea that return to original conditions is good merely because it is a return to original conditions. This was Aristophanes' thesis. Aristophanes argued that the goal of eros was to return us to our original condition of wholeness with our other halves. But Diotima explicitly rejects this thesis at $205 \mathrm{e}$. We would not want original conditions unless those original conditions were good, and thus we cannot assume that original conditions are always good. This is something which has to be determined. So the question remains, why is our original noetic condition good?

I have no doubt that Gordon can answer all these questions soundly. And good work in this field should generate controversy and disagreement. In this book Gordon has contributed greatly to the understanding of eros in Plato, and in particular to the appreciation of the significance of the topic outside what are traditionally held to be the erotic dialogues. And it is expected that more research will arise out of the important issues she raises in this work.

Recebido em junho de 2014, aprovado em setembro de 2014. 